\title{
Branch mortality influences phorophyte quality for vascular epiphytes
}

\begin{tabular}{|c|c|}
\hline Journal: & Botany \\
\hline Manuscript ID & cjb-2017-0023.R1 \\
\hline Manuscript Type: & Article \\
\hline Date Submitted by the Author: & 06-Apr-2017 \\
\hline Complete List of Authors: & $\begin{array}{l}\text { Cortes-Anzures, Beatriz ; Universidad Autónoma del Estado de Morelos, } \\
\text { Centro de Investigación en Biodiversidad y Conservación } \\
\text { Corona-López, Angélica; Universidad Autónoma del Estado de Morelos, } \\
\text { Centro de Investigación en Biodiversidad y Conservación } \\
\text { Toledo-Hernández, Victor; Universidad Autonoma del Estado de Morelos, } \\
\text { Centro de Investigación en Biodiversidad y Conservación (CIByC) } \\
\text { Valencia Díaz, Susana; Universidad Autonoma del Estado de Morelos, } \\
\text { Centro de Investigación en Biotecnología (CEIB) } \\
\text { Flores-Palacios, Alejandro; Universidad Autónoma del Estado de Morelos, } \\
\text { Centro de Investigación en Biodiversidad y Conservación; Universidad } \\
\text { Autónoma del Estado de Morelos--CIBYC }\end{array}$ \\
\hline $\begin{array}{l}\text { Please Select from this Special } \\
\text { Issues list if applicable: }\end{array}$ & $\mathrm{N} / \mathrm{A}$ \\
\hline Keyword: & $\begin{array}{l}\text { phorophyte-epiphyte association, plant-plant interactions, tropical dry } \\
\text { forest. }\end{array}$ \\
\hline
\end{tabular}

\section{SCHOLARONE ${ }^{\text {m }}$ \\ Manuscripts}


Branch mortality influences phorophyte quality for vascular epiphytes

Beatriz Olivia Cortes-Anzures, Angélica María Corona-López, Víctor Hugo ToledoHernández, Susana Valencia Díaz, and·Alejandro Flores-Palacios

\section{B. O. Cortes-Anzures, A. M. Corona-López, V. H. Toledo-Hernández and·A. Flores-}

Palacios. Centro de Investigación en Biodiversidad y Conservación (CIByC), Universidad Autónoma del Estado de Morelos. Av. Universidad 1001, Col. Chamilpa, Cuernavaca, 62209, Morelos, México. beatriz.cortes@uaem.mx, acorona@uaem.mx, victor.toledo@uaem.mx, alejandro.florez@uaem.mx

S. Valencia Díaz. Centro de Investigación en Biotecnología (CEIB), Universidad Autónoma del Estado de Morelos. Av. Universidad 1001, Col. Chamilpa, Cuernavaca, 62209, Morelos, México. E-mail: susana.valencia@uaem.mx

Corresponding author: Alejandro Flores-Palacios. Centro de Investigación en Biodiversidad y Conservación (CIByC), Universidad Autónoma del Estado de Morelos. Av. Universidad 1001, Col. Chamilpa, Cuernavaca, 62209, Morelos, México. Tel/Fax: +52 777 3297019, e-mail: alejandro.florez@uaem.mx 
Abstract: Trees generate resources for other guilds (e.g. lianas), including the production of supporting branches for the establishment of epiphytes. In a tropical dry forest of central Mexico, we studied whether branch mortality is associated with phorophyte quality. During a year, we monitored the survival of branches with and without vascular epiphytes in tree species with high (Bursera copallifera, B. glabrifolia) and low (B. fagaroides, Conzattia multiflora, Ipomoea pauciflora, Sapium macrocarpum) epiphyte loads. The lowest (Conzattia multiflora) and highest (Ipomoea pauciflora) branch mortalities occurred in phorophytes with low epiphyte loads, while branch mortality in Sapium macrocarpum was $60 \%$, and all of Bursera species had $<25 \%$. In Bursera copallifera and B. glabrifolia, the highest branch mortality was in branches with epiphytes, suggesting a negative influence of these plants, but mortality was also associated with larger/older branches. At the end of monitoring, 95\% of the epiphytes of Ipomoea pauciflora were growing on dead branches. We conclude that branch mortality is low in phorophytes with high epiphyte loads; but in phorophytes with low epiphyte loads, branches can be ephemeral or long lasting. Low epiphyte abundances in phorophytes with long-lasting branches can be caused by other traits that remain to be examined (e.g. seed capture).

Key words: phorophyte-epiphyte association, plant-plant interactions, tropical dry forest. 


\section{Introduction}

Trees are the dominant guild of the forests and facilitate the existence of other plant guilds (e.g. terrestrial herbs, epiphytes, lianas); for example, the production and fall of leaves condition the microclimate of the understory and provide resources to or act to limit some terrestrial herbs through biologically active compounds (Jones et al. 1994; Callaway et al. 2002; Valencia-Díaz et al. 2014). The identity of the trees as well as their attributes (e.g. architecture, bark peeling, allelopathic contents, branch lifespan) determine the abundance and vertical distribution of the epiphytes on them (Callaway et al. 2002, Krömer et al. 2007, López-Villalobos et al. 2008, Vergara-Torres et al. 2010, Valencia Díaz et al. 2010, Ruiz-Córdova et al. 2014).

While epiphytes can also grow on inert substrates, many of them mainly inhabit tree branches and the dynamic of branch survival and mortality therefore directly determines substrate availability for the epiphytes and thus their mortality (Chase 1987; Hietz 1997; Ruiz-Córdova et al. 2014; Sarmento Cabral et al. 2015).

Studies of the dynamic of populations of epiphytic plants suggest that the longevity of branches is a decisive factor in the maintenance of the populations. In some populations of epiphytes, it has been reported that recruitment of seedlings occurs frequently but in low numbers (Larson 1992; Ackerman et al. 1996; Hietz 1997; Tremblay 1997; Zotz 1998) and sporadic events of high recruitment are rare (Mondragón et al. 2004). The mortality of seedlings and juvenile individuals ranges from 30 to 50\% (Hietz 1997; Tremblay 1997; Zotz 1998) but can reach up to 70\% (Mondragón et al. 2004), associated mainly with drought. The detachment and falling of individuals, either alone or along with the branches that support them, is the main cause of death in the larger size categories (Hietz 1997). 
However, due to the low recruitment of seedlings, the most important stage for the growth of epiphytic populations is that of vegetative growth or survival of adults (Mondragón et al. 2004), which is directly dependent on branch longevity (Winkler et al. 2007). Thus it has been hypothesized that concentrations of epiphytes on trees occur in the strata where seed capture and adult survival are optimized (Ruiz-Cordova et al. 2014).

Only one study has examined the dynamic of branch fall (Hietz 1997). In a Mexican lower montane cloud forest it was found that the probability of an epiphyte falling together with its supporting branch increases inversely with the diameter of the branch. In branches $<4 \mathrm{~cm}$ in diameter, epiphyte mortality was around $45 \%$. For the epiphytic bromeliads Catopsis nutans (Sw.) Griseb., C. sessiflora (Ruiz \& Pav.) Mez, juveniles of Catopsis spp., Tillandsia butzii Mez and juveniles of Tillandsia spp., the highest mortality occurred because of branch fall, while in other species this occurrence was the second highest source of mortality.

Censuses of fallen branches found in an evergreen tropical forest, in Brazil and Panama suggest that the mortality of epiphytes due to falling branches is $4 \%$ per year and that this affects in particular those epiphytes that grow on thin branches (Sarmento Cabral et al. 2015). In fact, because of the short lifespan of these branches, the epiphytes that usually grow on these form a guild (twig epiphytes, Chase 1987), defined by species that share a small size, high growth rate and early reproductive age.

In the tropical dry forest of San Andrés de la Cal, central Mexico, it has been observed that epiphyte distribution is not random among phorophytes, or among their vertical strata (Vergara-Torres et al. 2010; Ruiz-Córdova et al. 2014). This suggests that the phorophytes differ in terms of their capacity to support the epiphytes. The phorophytes Bursera 
copallifera (DC.) Bullock, B. glabrifolia (Kunth) Engl. and B. bipinnata (DC) Engl. support a great abundance of epiphytes (i.e., they are preferred phorophytes). Other phorophytes have fewer epiphytes than might be expected from their abundance (i.e., limiting phorophytes, Vergara-Torres et al. 2010). This non-random distribution cannot be explained by the texture, thickness or incidence of peeling of bark among phorophyte species (Vergara-Torres et al. 2010). However, at least three species of limiting phorophytes contain substances that reduce germination of epiphyte species (Valencia-Díaz et al. 2010) and a higher frequency of xylophagous insects is present in the limiting phorophytes (Valencia-Díaz et al. 2014).

In addition to its effect on epiphyte phorophyte preference, it is possible that branch longevity also influences the vertical distribution of epiphytes. In B. copallifera and $B$. glabrifolia of the tropical dry forest of San Andrés de la Cal, epiphytes are more abundant on exterior branches of more than two centimeter in diameter but scarce on twigs of less than two centimeters in diameter as well as in the interior strata (Ruiz-Cordova et al. 2014). In the limiting phorophytes Conzattia multiflora (B.L. Rob.) Standl., Ipomoea pauciflora M. Martens \& Galeotti and Sapium macrocarpum Müll. Arg., however, epiphytes are more abundant on the trunk and scarce on the branches (Ruiz-Córdova et al. 2014). These distribution patterns do not correspond to either the stratification of light and humidity or to seed germination and early seedling survival (Ruiz-Córdova et al. 2014).

This study measured the survival of branches of different phorophytes within a tropical dry forest as a factor that determines both epiphytes phorophyte preference and vertical distribution. We hypothesized that the lifespan of branches is shorter in limiting phorophytes and that this contributes to their general deficit and explains the biased 
distribution of the epiphytes present on these phorophytes towards the lower strata (e.g. the trunk), while the opposite occurs on the branches of preferred phorophytes.

\section{Materials and methods}

Study area

This study was conducted in the ejido of San Andrés de la Cal in Tepoztlán, Morelos, central Mexico (18 $57^{\prime} 22.2^{\prime \prime} \mathrm{N}$ : 99 $\left.06^{\circ} 50.2^{\prime \prime} \mathrm{W}\right)$. The elevation ranges from 1480 to 1670 $\mathrm{m}$ a.s.1. The climate is classified as semi-warm subhumid (A) Cw2 (W) ig. This is the warmest of the temperate sub-humid climates, with rains in summer and winter, an annual average precipitation of $1200 \mathrm{~mm}$ and an average temperature of $20^{\circ} \mathrm{C}$ (Ruiz-Rivera 2001).

The dominant primary vegetation is tropical dry forest and two units of forests are differentiated in the zone, one that develops on soil derived from limestone rock and the other over a lava flow (Ruiz-Rivera 2001). This study was conducted in the former subunit, which is composed at least of 42 species of woody plants. The most abundant are Sapium macrocarpum (18\% of the individuals) (Euphorbiaceae), followed by Bursera fagaroides (Kunth) Engl. (15\% of individuals), B. glabrifolia (11\%) (Burseraceae), Ipomoea pauciflora (10\%) (Convolvulaceae), Conzattia multiflora (7\%) (Fabaceae) and I. murucoides Roem. \& Schult. (6\%), among others (Vergara-Torres et al. 2010). In this zone of forest, the epiphytic flora is comprised of 19 species, the most abundant of which is Tillandsia recurvata (L.) L. (71\% of the individuals) (Vergara-Torres et al. 2010).

\section{Field methods}

During the period from March to September 2011, following a transect of $900 \mathrm{~m}$, ten 
trees each of the species Bursera copallifera, B. fagaroides, B. glabrifolia, C. multiflora, I. pauciflora and S. macrocarpum were selected. A cohort of branches was marked on each tree (Table 1) with numbered aluminum labels and vinyl flagging tape. Branch mortality was monitored over one year and observations were done from the forest floor (with binoculars). On each occasion, when a branch disappeared from a tree, we search for it on the forest floor, and when a branch presented signs of decay, the tree was climbed to closely inspect the branch. The numbers of branches that fell and those that dried on the tree (dry standing) were recorded.

\section{Data analysis}

For analysis of branch survival, Kaplar-Meier curves were constructed for each tree species (Kleinbaum and Klein 2005), and log-rank tests were then performed in order to determine significant differences in the accumulated proportions of survivors (Kleinbaum and Klein 2005). In order to isolate which phorophyte species had different branch survival curves, paired Gehan-Wilcoxon tests were conducted (Hollander and Wolfe 1999). In this analysis, branches that were partially dry were considered to be dead, such that the analysis indicated how many branches or sections of branches died during the study as well as the date of death (considered as the date on which a dead section was first observed).

Finally, to test whether the proportion of epiphytes among dead branches differed among phorophyte species, the binomial method of comparison of more than two proportions (Zar 2010) was used, based on the $\chi^{2}$ test. In order to isolate tree species that differed from each other, multiple comparisons were carried out among proportions (Zar 2010). 


\section{Results}

We tried as much as possible to obtain the same number of branches among tree species, and within each species, a similar number of branches with and without epiphytes, but this was complicated by the fact that C. multiflora, I. pauciflora and S. macrocarpum presented few branches with epiphytes (Table 1). A total of 194 branches of B. copallifera, 165 of B. fagaroides, 180 of B. glabrifolia, 96 of C. multiflora, 104 of I. pauciflora, and 109 of $S$. macrocarpum (59 trees and 848 branches, Table 1) were marked. In $B$. copallifera, branches with epiphytes presented greater diameters than those without $(\mathrm{t}=$ 3.0, $\mathrm{P}<0.01)$ but not lengths $(\mathrm{t}=0.5, \mathrm{P}=0.58)$ (Table 1$)$. In $B$. glabrifolia $($ diameter, $\mathrm{t}=$ $3.80 \mathrm{P}<0.001$; length, $\mathrm{t}=2.6, \mathrm{P}<0.01)$ and $C$. multiflora (diameter, $\mathrm{t}=5.1, \mathrm{P}<0.00001$; length, $\mathrm{t}=4.7, \mathrm{P}<0.00001)$, branches with epiphytes were thicker and longer than those without. Branches of B. fagaroides, I. pauciflora and S. macrocarpum, with and without epiphytes, were similar in both diameter $(\mathrm{t}=0.7, \mathrm{P}>0.05 ; \mathrm{t}=3.3, \mathrm{P}<0.01 ; \mathrm{t}=2.6, \mathrm{P}<$ 0.01 , respectively) and length $(\mathrm{t}=2.0, \mathrm{P}<0.05 ; \mathrm{t}=0.6, \mathrm{P}>0.05 ; \mathrm{t}=1.9, \mathrm{P}>0.05$, respectively) (Table 1$)$.

Branch survival differed among species $\left(\chi^{2}=228.0, \mathrm{P}<0.00001\right)($ Fig. 1$)$. The highest survival occurred in the branches of $C$. multiflora. Branches of the three species of the genus Bursera presented similar survival at greater than $75 \%$, while $S$. macrocarpum presented a survival of $40 \%$ and the lowest survival occurred in I. pauciflora (Fig. 1).

In B. copallifera $\left(\chi^{2}=2.6, \mathrm{P}<0.05\right)$ and in B. glabrifolia $\left(\chi^{2}=2.0, \mathrm{P}<0.05\right)$, survival differed between branches with and without epiphytes. In both species, the highest mortality occurred in branches with epiphytes (Fig. 2). In B. fagaroides $\left(\chi^{2}=1.4, P=0.17\right)$, 
C. multiflora $\left(\chi^{2}=0.2, \mathrm{P}=0.85\right)$, I. pauciflora $\left(\chi^{2}=1.1, \mathrm{P}=0.28\right)$ and S. macrocarpum $\left(\chi^{2}\right.$ $=1.4, \mathrm{P}=0.17)$, survival of branches was similar regardless of the presence or absence of epiphytes (Fig. 2).

The dry percentage in the branches differed only in B. copallifera, regardless of the presence or absence of epiphytes (Table 2). In the branches of this species, a greater dry area was found in those that did not host epiphytes $(\mathrm{t}=2.1, \mathrm{P}<0.05)$. The branches of $B$. fagaroides $(\mathrm{t}=0.2, \mathrm{P}=0.83)$, B. glabrifolia $(\mathrm{t}=1.7, \mathrm{P}=0.092)$ and I. pauciflora $(\mathrm{t}=0.3, \mathrm{P}$ $=0.74$ ) showed similar percentages of dead area, with or without epiphytes. In $C$. multiflora and S. macrocarpum, the low number of branches with a dry area, among those that had epiphytes, impeded the determination of whether epiphytes increased the percentage of dry area (Table 2).

The percentage of epiphytes that, at the end of the study, were growing on dry branches or had fallen with their branches differed among phorophyte species $\left(\chi^{2}=146.4, \mathrm{P}\right.$ $<0.0001)$. The highest percentage of epiphytes on dry branches occurred in I. pauciflora (Table 3). In B. copallifera, B. glabrifolia, C. multiflora and S. macrocarpum the percentage was intermediate. And the lowest percentage tended to occur in B. fagaroides (Table 3).

\section{Discussion}

The probability of an epiphyte falling together with its phorophyte branch is related to the size of the branch (Hietz 1997; Sarmento Cabral et al. 2015) and branch mortality is a key factor in the persistence of epiphyte populations in the canopy (Winkler et al. 2007). An understanding of the causes of branch mortality is therefore of great importance to the 
management of epiphytes and could help to explain why certain phorophyte species and vertical strata are preferentially inhabited. The general hypothesis of this study was that branch mortality would occur less frequently in phorophytes that concentrate epiphytes, but be higher in limiting phorophytes, making branch mortality a factor that influences the quality of the phorophyte for the epiphytes and thus their vertical distribution on these phorophytes.

The low branch survival in I. pauciflora and S. macrocarpum supports the hypothesis that branch survival determines both phorophyte quality and the vertical distribution of epiphytes, since I. pauciflora and S. macrocarpum are limiting phorophytes at the study site and the epiphytes are concentrated on their lower strata (Ruiz-Córdova et al. 2014; Vergara-Torres et al. 2010). Ipomoea pauciflora was the phorophyte with the lowest branch survival and is a tree associated with rocky outcrops within the forest or with recovery zones within the forest, suggesting that it is a short-lived pioneer species (Sotelo-Caro 2016), and is one in which the branches die rapidly. Moreover, the bark of this species contains allelopathic compounds that act to reduce epiphyte germination (Valencia-Díaz et al. 2010). The release of these compounds is related to the presence of plants that use the bark as a structural support as well as to the activity of borer insects (Valencia-Díaz et al. 2014). Through branch mortality alone, $95 \%$ of the individual epiphytes monitored in Ipomoea pauciflora fell with their branches or were found to be growing on dry branches. These data suggests that for Ipomoea pauciflora and Sapium macrocarpum the short lifespan life of their branches, added to the presence of allelopathic substances in Ipomoea pauciflora, could explain both the low abundance of epiphytes and their vertical stratification, concentrated on the trunks (Ruiz-Córdova et al. 2014). The high branch 
survival in $B$. fagaroides and $C$. multiflora suggests that this is not the characteristic that makes these species limiting phorophytes. A previous study of $C$. multiflora found that, while Tillandsia seeds do disperse to this trees species, their branches retain four to five times fewer seeds compared with branches of Bursera copallifera, probably because of a lower branch density (which generates less turbulence) and a smooth bark free of resins (Victoriano-Romero et al. 2017). Such low seed capture can help to explain why this is a limiting phorophyte. For both $B$. fagaroides and $C$. multiflora, the possibility that their bark may contain phytochemicals that reduce the germination of epiphyte seeds cannot be discounted. These compounds have been found in other sympatric limiting phorophytes (Valencia-Díaz et al. 2010).

The branch survival rates of phorophytes that concentrate epiphytes supported our hypothesis and their branches presented the highest (B. copallifera) or second highest $(B$. glabrifolia) rates of survival. Contrary to expectation, in these phorophytes only, the branches with epiphytes presented higher mortality than those without. In the other phorophyte species, branch mortality was independent of the presence of epiphytes and it was thus impossible to generalize regarding the effect of the epiphytes on their phorophytes or whether the effect of the epiphytes on the trees was density-dependent (Flores-Palacios 2016).

In general, there was no unequivocal detection of the causes of branch mortality, but in phorophytes with high epiphyte loads, the presence of these was associated with an increase in branch mortality. It is possible that branches with epiphytes are weakened by this load and that this weakness may favor the entry of pathogens (Valencia-Díaz et al. 2014); however, the mechanisms through which the epiphytes weaken the branches remains 
unclear. Other experimental studies have shown that Tillandsia recurvata has a negative effect on Prosopis laevigata, a tree that is massively colonized in the desert of Chihuahua. In this case, it is suggested that the effect of T. recurvata could be manifested through phytochemicals modifying the transport tissues of the tree (Flores-Palacios et al. 2015). However, in a study where epiphytes were artificially removed and transplanted, branch mortality was independent of the presence of epiphytes (Flores-Palacios 2016). In $B$. copallifera and B. glabrifolia, the branches supporting highest epiphyte abundance were larger, suggesting that, rather than a direct effect caused by the epiphytes, these may in fact be senescent branches (Flores-Palacios 2016). The mortality of branches associated to the presence of epiphytes, instead of being caused by these, has been explained as a correlation caused by the fact than older/decaying branches have been exposed for more time to the colonization of epiphytes (Flores-Palacios 2016). Further experimentation is therefore necessary in order to test whether the epiphytes truly weaken the branches of these phorophytes and allow the entry of pathogens or borer insects, or whether these are senescent branches. There is evidence that suggests that the presence of epiphytes may be beneficial for the trees through improvement of the branch microclimate (Stanton et al. 2014). This could explain why branches of B. copallifera with epiphytes presented fewer dry areas than those without.

The data produced by this study support the notion that trees that concentrate populations of epiphytes present higher branch survival than trees where epiphytes are scarce. While high branch mortality does not necessarily occur in trees with few epiphytes, the data show that epiphyte mortality in tropical dry forest, caused by branch death, is greater than that recorded in a lower montane cloud forests (Winkler et al. 2007), where 
mortality ranged from 1.8 to $9.8 \%$ of the plants. Maybe the higher branch mortality observed in this tropical dry forest is caused by the long-lasting dry season (up to six months) that generates small trees, while in montane cloud forests the dry season is almost absent or is less severe because of the high incidence of fog. In the tropical dry forest studied, the minimum mortality associated with falling branches was $10 \%$ of the epiphytes. This underlines the importance of branch mortality as a determinant factor in the richness and abundance of vascular epiphytes.

\section{Acknowledgements}

Thanks to L. M. Ayestarán-Hernández, J. Pérez Cruz, A. Duran Rivera, G. Ortega Solano, S. Arechaga Ocampo, M. I. Figueroa Rodríguez, M. Castellanos Mojica who helped during fieldwork. The comments and criticism of J. C. Sandoval-Manrique, A. Flores-Morales, K. MacMillan, C. Lacroix and two anonymous reviewers improved the manuscript. This research was supported by a PROMEP grant to the Cuerpo Académico de Biología del Dosel through the research network "Sistemática y Ecología en Comunidades Forestales y Cultivos" (PROMEP/103.5/09/1187, folio 13). An early version of the manuscript was presented by BOCA as a Bachelors thesis at the Faculty of Biological Sciences, Universidad Autónoma del Estado de Morelos, México.

\section{References}

Ackerman, J.D., Sabat, A., and Zimmerman, J.K. 1996. Seedling establishment in an epiphytic orchid: an experimental study of seed limitation Oecologia 106(2): 192-198. doi:10.1007/BF00328598. 
Callaway, R.M., Reinhart, K.O., Moore, G.W., Moore, D.J., and Pennings, S.C. 2002. Epiphyte host preferences and host traits: mechanisms for species-specific interactions. Oecologia 132(2):221-230. doi:10.1007/s00442-002-0943-3.

Chase, M.W. 1987. Obligate twig epiphytism in the Oncidiinae and oher neotropical orchids. Selbyana 10(1): 24-30. Available from URL:http://www.jstor.org/stable/41759748.

Flores-Palacios, A., Corona-López, A.M., Rios, M.Y., Aguilar-Guadarrama, B., ToledoHernández, V.H., Rodríguez-López, V., and Valencia-Díaz, S. 2015. Is allelopathic activity of Ipomoea murucoides induced by xylophage damage? PLoS ONE 10(12): e0143529. doi:10.3771/journal.pone.0143529.

Flores-Palacios, A. 2016. Does structural parasitism by epiphytes exist? A case study between Tillandsia recurvata and Parkinsonia praecox. Plant Biol. 18(3): 463-470. doi:10.1111/plb.12406.

Hietz, P. 1997. Population dynamics of epiphytes in a Mexican humid montane forest. J. Ecol. 85(6): 767-775. doi:10.2307/2960600.

Hollander, M., and Wolfe, D.A. 1999. Nonparametric statistical methods. John Wiley \& Sons, New York.

Jones, C.G., Lawton, J.H., and Shachak, M. 1994. Organisms as ecosystem engineers. Oikos 69(3): 373-386. doi:10.2307/3545850.

Kleinbaum, D.G., and Klein, M. 2005. Survival Analysis. Springer, New York.

Krömer, T., Kessler, M., and Gradstein, S.R.. 2007. Vertical stratification of vascular epiphytes in submontane and montane forest of the Bolivian Andes: the importance of the understory. Plant Ecology 189(2): 2 261-278. doi: 10.1007/s11258-006-9182-8. 
Larson, R.J. 1992. Population dynamics of Encyclia tampensis in Florida. Selbyana 13(1): 50-56. . Available from URL:http://www.jstor.org/stable/41759792.

López-Villalobos, A., Flores-Palacios, A., and Ortiz-Pulido, R. 2008. The relationship between bark peeling rate and the distribution and mortality of two epiphyte species. Plant Ecol. 198(2): 265-274. doi:10.1007/s11258-008-9402-5.

Mondragón, D., Durán, R., Ramírez, I., and Valverde, T. 2004. Temporal variation in the demography of the clonal epiphyte Tillandsia brachycaulos (Bromeliaceae) in the Yucatán Peninsula, Mexico. J. Trop. Ecol. 20(2): 97-104. doi:10.1017/S0266467403001287.

Ruiz-Cordova, J.P., Toledo-Hernández, V.H., and Flores-Palacios, A. 2014. The effect of substrate abundance in the vertical stratification of bromeliad epiphytes in a tropical dry forest (Mexico). Flora 209(8): 375-384. doi:10.1016/j.flora.2014.06.003.

Ruiz-Rivera, C.A. 2001. San Andrés de la Cal: culto a los señores del tiempo en rituales agrarios. Universidad Autónoma del Estado de Morelos. Cuernavaca.

Sarmento Cabral, S., Petter. G., Mendieta-Leiva, G, Wagner, K., Zotz, G, and Kreft, H. 2015. Branchfall as a demographic filter for epiphyte communities: lessons from forest floor-based sampling. PLoS ONE 10(6):

e01280019.doi:10.1371/journal.pone.0128019. doi:10.1371/journal.pone.0128019.

Sotelo-Caro, O. 2016. Evaluación de la estructura del bosque tropical caducifolio en la subcuenca del río Apatlaco y su relación con procesos hidrológicos. PhD Thesis, Dependencia de Educación Superior de Ciencias Naturales, Universidad Autónoma del Estado de Morelos, Cuernavaca.

Stanton, D.E., Huallpa Chávez, J., Villegas, L., Villasante, F., Armesto, J., Hedin, L.O., and 
Horn, H. 2014. Epiphytes improve host plant water use by microenvironmental modification. Funct. Ecol. 28(5): 1274-1283. doi:10.1111/1365-2435.12249.

Tremblay, R.L. 1997. Lepanthes caritensis, an endangered orchid: no sex, no future?

Selbyana 18(2): 160-166. Available from URL:http://www.jstor.org/stable/41760428.

Valencia-Díaz, S., Flores-Palacios, A., Rodríguez-López, V., Ventura-Zapata, E., and

Jiménez-Aparicio, A.R. 2010 Effect of host-bark extracts on seed germination in Tillandsia recurvata, an epiphytic bromeliad. J. Trop. Ecol. 26(6): 571-581. doi:10.1017/S0266467410000374

Valencia-Díaz, S., Corona-López, A.M., Toledo-Hernández, V.H., and Flores-Palacios, A. 2014. Is branch damage by xylophages related to the presence of epiphytes? Arthropod-Plant Interactions 8(1): 25-32. doi:10.1007/s11829-013-9284-X. Vergara-Torres, C.A., Pacheco-Álvarez, M.C., and Flores-Palacios, A. 2010. Host preference and host limitation of vascular epiphytes in a tropical dry forest of central Mexico. J. Trop. Ecol. 26(6): 563-570. doi:10.1017/S0266467410000349.

Victoriano-Romero, E., Valencia-Díaz, S., Toledo-Hernández, V.H., and Flores-Palacios, A. 2017. Dispersal limitation of Tillandsia species correlates with rain and host structure in a central Mexican tropical dry forest. PLoS ONE 12(2): e0171614. doi:10.1371/journal.pone.0171614

Winkler, M., Hülber, K., and Hietz, P. 2007. Population dynamics of epiphytic bromeliads: Life strategies and the role of host branches. Basic Appl. Ecol. 8(2): 183-196. doi:10.1016/j.baae.2006.05.003.

Zar, J.H. 2010. Biostatistical analysis. Pearson Education, Inc., New Jersey. Zotz, G. 1998. Demography of the epiphyte orchid, Dimerandra emarginata. J. Trop. Ecol. 
14(6): 725-741. doi:10.1017/S0266467498000534.

https://mc06.manuscriptcentral.com/botany-pubs 
1 Table 1. Mean ( \pm SD) values of the diameter at breast height (DHB) of six tree species and, the mean branch diameter and

2 length of branches, with or without epiphytes, used to monitor branch survival during a year in a tropical dry forest of San

3 Andrés de la Cal, Tepoztlán, center of Mexico.

\begin{tabular}{|c|c|c|c|c|c|c|c|c|}
\hline Tree & $\mathrm{n}$ & $\mathrm{DBH}$ & & $\mathrm{n}$ & Branch & Branch & \multicolumn{2}{|c|}{ Epiphytes } \\
\hline species & (trees) & $(\mathrm{cm})$ & $\begin{array}{c}\text { of } \\
\text { epiphytes }\end{array}$ & (branches) & diameter $(\mathrm{cm})$ & length $(\mathrm{cm})$ & $\begin{array}{c}\text { Number per } \\
\text { branch }\end{array}$ & Total \\
\hline Bursera & 10 & 25.86 & Without & 95 & $1.97 \pm 0.40$ & $90.24 \pm 39.12^{\mathrm{ns}}$ & $0.00 \pm 0.00$ & 0 \\
\hline copallifera & & \pm 5.25 & With & 99 & $2.18 \pm 0.52^{*}$ & $93.14 \pm 34.68$ & $3.78 \pm 3.58$ & 374 \\
\hline Bursera & 10 & 23.46 & Without & 92 & $3.35 \pm 10.31^{\mathrm{ns}}$ & $125.80 \pm 42.30^{\mathrm{ns}}$ & $0.00 \pm 0.00$ & 0 \\
\hline fagaroides & & \pm 4.48 & With & 73 & $2.52 \pm 0.70$ & $137.95 \pm 48.34$ & $3.05 \pm 4.42$ & 223 \\
\hline Bursera & 9 & 26.18 & Without & 89 & $2.08 \pm 0.44$ & $113.90 \pm 41.98$ & $0.00 \pm 0.00$ & 0 \\
\hline glabrifolia & & \pm 5.69 & With & 91 & $2.36 \pm 0.52^{*}$ & $132.70 \pm 53.50^{*}$ & $5.43 \pm 5.04$ & 494 \\
\hline Conzattia & 10 & 37.15 & Without & 74 & $2.26 \pm 0.90$ & $104.26 \pm 57.66$ & $0.00 \pm 0.00$ & 0 \\
\hline multiflora & & \pm 6.38 & With & 22 & $3.52 \pm 1.32^{*}$ & $177.10 \pm 83.20^{*}$ & $1.68 \pm 1.81$ & 37 \\
\hline Ipomoea & 10 & 18.28 & Without & 86 & $2.06 \pm 0.62^{\mathrm{ns}}$ & $132.12 \pm 83.00^{\mathrm{ns}}$ & $0.00 \pm 0.00$ & 0 \\
\hline
\end{tabular}




\begin{tabular}{|c|c|c|c|c|c|c|c|}
\hline pauciflora & & \pm 6.85 & With & 18 & $2.64 \pm 0.95$ & $144.50 \pm 70.81$ & $2.17 \pm 1.65$ \\
\hline Sapium & 10 & 24.87 & Without & 105 & $1.93 \pm 0.55^{\mathrm{ns}}$ & $95.87 \pm 33.09^{\mathrm{ns}}$ & $0.00 \pm 0.00$ \\
\hline macrocarpum & & \pm 14.02 & With & 4 & $2.70 \pm 1.00$ & $128.75 \pm 49.92$ & $2.25 \pm 2.50$ \\
\hline
\end{tabular}

$1 . *$ significant differences in the mean values between branches with and without epiphytes within the same tree species $(\mathrm{t}$ test,

$2 \mathrm{P}<0.05)$

3 n.s. $=$ non-significant differences. 
1 Table 2. Number of branches with dead sections and their percentage of dead material

2 (mean $\pm \mathrm{SD})$ in branches of six tree species, with or without epiphytes, in the tropical dry

3 forest of San Andrés de la Cal Tepoztlán, central Mexico.

\begin{tabular}{|c|c|c|c|}
\hline Tree species & $\begin{array}{l}\text { Presence of } \\
\text { epiphytes }\end{array}$ & $\begin{array}{c}\text { Number of branches } \\
\text { with dead sections }\end{array}$ & $\begin{array}{c}\text { Percentage of dead } \\
\text { material } \\
\text { in each branch }\end{array}$ \\
\hline Bursera & Without & 11 & $89.70 \pm 14.52$ \\
\hline copallifera & With & 26 & $69.84 \pm 30.38$ \\
\hline Bursera & Without & 26 & $70.27 \pm 32.79$ \\
\hline fagaroides & With & 14 & $72.59 \pm 35.07$ \\
\hline Bursera & Without & 15 & $46.72 \pm 35.67$ \\
\hline glabrifolia & With & 27 & $66.51 \pm 35.67$ \\
\hline Conzattia & Without & 10 & $50.50 \pm 42.15$ \\
\hline multiflora & With & 3 & $68.00 \pm 55.42$ \\
\hline Ipomoea & Without & 69 & $67.54 \pm 36.07$ \\
\hline pauciflora & With & 16 & $70.80 \pm 34.07$ \\
\hline Sapium & Without & 62 & $69.08 \pm 30.84$ \\
\hline macrocarpum & With & 1 & $49.41 \pm 0.00$ \\
\hline
\end{tabular}


1 Table 3. Percentage of epiphytes that, following the one-year monitoring period, were

2 supported by dead branches (fallen or still attached) in six tree species of the tropical dry

3 forest of San Andrés de la Cal, Tepoztlán, center of Mexico. Different letters indicate

4 significant differences between the percentages (Tukey-like test for more than two

5 proportions, $\mathrm{P}<0.05)$.

\begin{tabular}{cc}
\hline Tree species & Percentage of epiphytes \\
& supported on dead branches \\
\hline Bursera copallifera & $31 \%^{\mathrm{b}}$ \\
Bursera fagaroides & $10 \%^{\mathrm{d}}$ \\
Bursera glabrifolia & $21 \%^{\mathrm{bc}}$ \\
Conzattia multiflora & $11 \%^{\mathrm{bcd}}$ \\
Ipomoea pauciflora & $95 \%^{\mathrm{a}}$ \\
Sapium macrocarpum & $11 \%^{\mathrm{bcd}}$ \\
\hline
\end{tabular}




\section{Figure captions}

3 Fig. 1. Branch survival curves of six tree species monitored for a period of one year in a

4 tropical dry forest of central Mexico. Different letters indicate significant differences

5 between species (paired Gehan-Wilcoxon test, $\mathrm{P}>0.05$ ).

6 Fig. 2. Survival curves of branches with (continuous lines ) or without (dotted lines)

7 epiphytes in six tree species monitored for a period of one year in a tropical dry forest of

8 central Mexico. $\mathrm{P}$ values indicate significant differences between branches with and

9 without epiphytes within the same tree species $(\log$ rank test $)$. n.s. = non-significant

10 differences. 
Page 23 of $24^{\cdots \cdots}$ B. copallifera

... B. glabrifolia

Botany $\leadsto$ B. fagaroides

- $\Delta$ - C. multiflora

- - I. pauciflora

- - S. macrocarpum

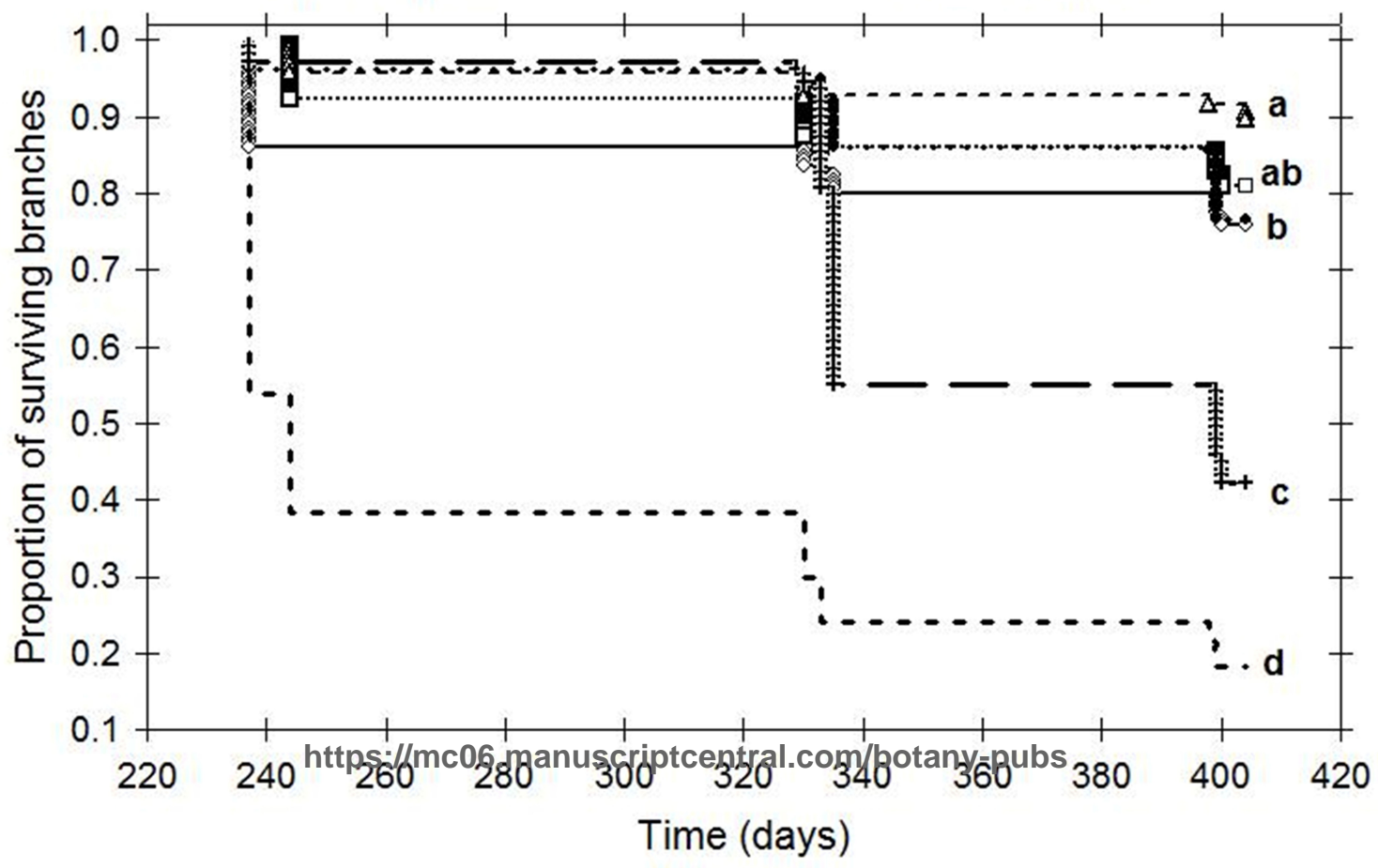


